\title{
Subjective well-being in European countries- on the age-specific impact of physical activity
}

\author{
Tim Pawlowski • Paul Downward • Simona Rasciute
}

Received: 26 January 2011 / Accepted: 1 July 2011 /Published online: 22 July 2011

(C) European Group for Research into Elderly and Physical Activity (EGREPA) 2011

\begin{abstract}
As an attempt to measure the 'experienced' utility of individuals in economics, the investigation of individuals' subjective well-being (SWB) was pioneered by Van Praag and Frijters (1999) and Kahneman et al. (1999). Since then, a number of studies has analysed the factors associated with SWB and policy makers are now recognising the importance of SWB as a policy target, with the implication being that one could target its factors associated with increase in the overall SWB in countries. However, despite its significance to economies, and increasing policy relevance, investigations on the impact of sport and physical activity on SWB are relatively rare [e.g. Rasciute and Downward in Kyklos 63(2):256-270, 2010]. More specifically, despite sports participation and engagement in physical activity having a strong age-specific profile (Breuer et al. in Eur Rev Aging Phys Act 7:61-70, 2010; Hinrichs et al. in Eur J Sport Soc 6(1):49-57, 2010; Mechling and Netz in European Rev Aging Physical Activity 6(2):89-97, 2009), there is no study that investigates whether the magnitude of this impact is age-specific. Consequently, this paper seeks to make a unique contribution to the existing literature by exploring the age-specific
\end{abstract}

\author{
T. Pawlowski $(\bowtie)$ \\ Institute of Sport Economics and Sport Management, \\ German Sport University Cologne, \\ Am Sportpark Müngersdorf 6, \\ 50933 Köln, Germany \\ e-mail: pawlowski@dshs-koeln.de

\section{P. Downward} \\ Institute of Sport and Leisure Policy, Loughborough University, \\ Leicestershire LE11 3TU, UK \\ S. Rasciute \\ Department of Economics, Loughborough University, \\ Leicestershire LE11 3TU, UK
}

effects of physical activity on SWB for a broad crosssection of 19 European countries. Overall, the results suggest that engagement in physical activity generally contributes to the SWB of individuals on a European level but that significant age-specific differences exist.

Keywords Well-being · Happiness · Physical activity · Age Sport - Generalized method of moments (GMM)

\section{Introduction}

As an attempt to measure the 'experienced' utility of individuals in economics, the investigation of individuals' subjective well-being (SWB) was pioneered by Van Praag and Frijters [40] and Kahneman et al. [27]. Since then, a large number of studies has analysed the factors associated with SWB. These theoretical and empirical developments are both promising and timely since they have helped to stimulate recognition of the importance of SWB as a social welfare measure and target for policy makers. Understanding the factors associated with SWB will thus be central to policy implementation. However, while previous research has primarily focused on the impact of personal characteristics (such as age, gender, health and education) and external characteristics (such as political and economic reunification in Germany), investigations of the impact of sport on SWB are rare. ${ }^{1}$ This is surprising on two counts. First, sport is of growing significance to economies. In recognition of this, the European Union (EU) is producing

\footnotetext{
${ }^{1}$ In the following, the terms 'sports' and 'physical activity' are used interchangeably. The relevant question in the survey used in our study is 'How often do you take part in physical activities such as sports, going to the gym, going for a walk?' This means that sports is analysed in a broader sense here.
} 
Satellite Accounts to chart the macroeconomic significance of the sector and to inform EU strategy. ${ }^{2}$ Sport has also become of significance for health and social public policy. On this basis, progressive governments in the 1990s and 2000s have sought to encourage sports participation and to host major sports events. ${ }^{3}$ Significantly, recent policy has also suggested that hosting major sporting events can act as a catalyst to promote participation and thereby indirectly generating health and SWB benefits. Moreover, it is argued that hosting major events can have direct effects on SWB through the 'feel-good' factor following sporting success $[10,12,29,32]$. Second, an important feature of the concept of 'experienced' utility is that preferences are presented as not just reflecting individual self interest, but that they also capture 'externalities' such as altruism and the relativity of utility associated with social comparison. This means that utility can be associated with the social interactions implied in consumption [19, 20]. Social interactions can arise in the consumption of 'relational goods', whose consumption directly leads to increases in individual utility to others $[3,23]$. Since the consumption of sports can clearly be linked to social interactions and relational goods, the decision to undertake a sports activity must logically be associated with an increase in the SWB of a rational utility maximising individual.

Whilst growing evidence exists that sports participation increases SWB, e.g. [36], there is no study that investigates whether the magnitude of this impact is age-specific, although, it is also well known that sport participation is strongly influenced by age $[5,12,24,33]$. Consequently, this paper seeks to make a unique contribution to the existing literature by exploring the age-specific effects of sports participation on SWB for a broad cross-section of 19 European countries.

To address this issue, 'State of research' section briefly reviews the literature that has recently assessed the impact of sport and physical activity as well as other factors upon SWB. 'Methods' section outlines the data and variables employed in this study as well as the modelling techniques used to analyse the data to produce robust estimates.

\footnotetext{
${ }^{2}$ Initial analysis suggests, for example, that sport comprises between $3 \%$ and $3.7 \%$ of consumer expenditure, $2.2 \%$ and $4.0 \%$ of gross value added and $2.0 \%$ and $5.8 \%$ of employment across countries [15, available at $\mathrm{http} / /$ ec.europa.eu/sport/library/doc/b1/madrid_forum sport_satellite_account_leaflet.pdf, accessed 14 June 2011].

${ }^{3}$ The World Health Organisation estimates that up to $60 \%$ of the world's population does not undertake the physical activity required to obtain health benefits, which are also identified as a component of SWB [36]. Such inactivity translates into considerable health care costs equivalent to $£ 2$ billion for the UK [10]; Canadian $\$ 2.1$ billion, which is about $2.5 \%$ of the total, in Canada [28]; US $\$ 24.3$ billion or $2.4 \%$ of the total for the USA [9] and CHF2.4 billion or $16 \%$ of total health care costs for Switzerland [38].
}

'Results' section presents the results and 'Discussion and conclusion' section offers the main conclusions to the paper.

\section{State of research}

A number of studies exist that has previously analysed the factors associated with SWB. For instance, the impact of income on SWB is identified to be positive, though subject to some considerable discussion arising from the 'Easterlin paradox' [14], in which rising real incomes have not been correlated with rising levels of SWB over time. Yet, crosssectional studies identify a positive effect of income on SWB $[4,37]$ as do panel data studies $[8,16,17,21,41]$. An explanation offered by Frey and Stutzer [19] is that it is relative income that ultimately affects SWB because of the relativity of individual's judgments. Of course in a crosssection context for any given comparator income, absolute and relative incomes will be perfectly correlated as income is simply rescaled. The literature also argues that employment and self-employment tends to increase well-being, in contrast to unemployment $[1,37,41]$. Furthermore, although it is argued that the levels of education are not closely linked to the levels of SWB [37] one might expect that higher levels of education will be associated with higher reported SWB through higher income as these are likely to be correlated. Indeed, Powdthavee [35] has recently argued that income impacts are likely to be biased in much research because of endogenity problems. Further, the literature suggests a U-shaped relationship between age (and consequently age-squared) and SWB [37, 41, 42] and an impact of the marital status on SWB. It is found that being married raises SWB compared to being divorced, separated or having suffered bereavement. The latter has the largest (and negative) effect [34]. In the case of divorce, it is found that SWB reduces more for females than for males [7] but that those who remarry recover their initial levels of SWB [26]. However, the direct effects of gender are rarely discussed. $^{4}$

So far, as could be identified, five major published studies have previously investigated the impact of sports participation on SWB. Becchetti et al. [3] examine the German Social Economic Panel (GSOEP) to see how ordered variables measuring the frequency of attending social gatherings, attending cultural events, participation in sports, performing volunteer work and attending church or religious events affect an ordered measure of life satisfaction. These covariates are presented as relational goods.

\footnotetext{
${ }^{4}$ A number of studies exists that have previously analysed further factors associated with SWB. Since those factors have not been inquired in the survey used in this study, we have omitted them from our discussion.
} 
Other standard covariates are employed as indicated in the introduction. Treating the dependent variables as continuous, ordinary least squares (OLS) and fixed effects models are estimated with the result that the relational goods, including sports participation individually and collectively increase life satisfaction.

Lechner [30] also uses the GSOEP in a complex research design that explores how sports participation affects monthly earnings and hourly wages; health measures (days unable to work, two ordinal measures of subjective health including the subject's own view of their health and their satisfaction with their health) as well as ordinal indicators measuring whether the individual is worried or not about the economic situation and their general satisfaction with life. Lechner exploits the panel structure of the data differently than simply using instrumental variables and lags in the research design. A matching estimator is applied to subsamples which are defined so that sports participation for individuals is initially the same. The impact of subsequent changes in this covariate over time is then explored. Significant effects of sport participation upon the SWB of males are identified but positive and insignificant effects for females.

Based on cross-section UK data from the Taking Part Survey, Rasciute and Downward [36] explore how a binary variable measuring participation in any of 67 sports, as well as binary variables measuring walking and cycling activity affect ordinal measures of happiness and subjectively defined health. The walking variable was disaggregated to account for both recreational and utilitarian walking. Similarly, recreational, utilitarian and sport forms of cycling activity were also identified. Bivariate probit, ordered probit and seemingly unrelated regression estimates were obtained to try to account for unobserved relationships between happiness and health. It was found that sports participation and walking have a positive effect on both the individual's health and happiness. However, whilst cycling has health benefits, it also appears to involve some negative impact on happiness, which could be the disutility associated with traffic congestion.

Downward and Rasciute [13] also make use of the Taking Part Survey to analyse the effects of sports participation on SWB, defined as an ordinal variable measuring happiness. In this paper, a heterogeneous threshold-ordered probit estimator is employed to establish if different effects on SWB are due to sports that have more social interactions associated with them than others. This might be the case in activities such as team sports and sports undertaken with a partner such as racquet sports. The results show that sports participation increases SWB generally, but more so in the context of social interactions. Monetary evaluations of the impacts are also provided.

Finally, and as an exception to the economic studies that have made use of larger scale data sets, Lee and Park [31] employ a small primary data study for the Korean Sports Association to examine the impact of physical activity on the SWB of the disabled. SWB is either an overall ordinal measure of life satisfaction or it is an average of five ordinal scales measuring items associated with life satisfaction. Ordered probit and ordered logit estimators were applied to the former dependent variable and OLS to the latter. Controlling for six different types of physical disability, it is shown that sports participation raises the probability of higher levels of SWB. Table 1 summarizes the studies and the central findings discussed above.

Some important working papers also exist such as Forrest and McHale [18] and Huang and Humphreys [25]. A significant contribution of these papers is that they make use of information on facilities to help control for the endogeneity between participation in sport and SWB. They also find positive effects of sports participation on SWB. The issue of endogeneity is an important one and is controlled for in this study using instrumental variables as discussed in the next section.

Summing up, the published literature suggests that (amongst other covariates) sports participation does have an impact on SWB. However, since sports participation itself is influenced by age ${ }^{5}$, this article provides a unique contribution by exploring the age-specific effects of sports participation on SWB.

\section{Methods}

The data employed in this analysis draw on the International Social Survey Programme, currently comprising 46 member countries. Data are collected on a variety of social, economic and environmental themes; and in 2007, it investigated sports and leisure activities through a leisure time and sports module. In the current research, a sample size of $n=19,036$ is obtained from 19 European countries. ${ }^{6}$

In line with previous research (e.g. [3]) and the research questions posed, the dependent variable measuring SWB is a happiness variable (happy) and it is treated as continuous with the four categories being not at all happy $(=1)$, not very happy $(=2)$, fairly happy $(=3)$ and very happy $(=4)$.

Prompted by the general literature on SWB the analysis controls for standard determinants. These include age in

\footnotetext{
${ }^{5}$ The impacts of age appear to depend heavily on the research design. For instance, cross-sectional studies assume that sports participation decrease with age while a longitudinal study conducted by Breuer and Wicker [4] assumes increasing physical activity with age. A summary of previous findings and a discussion on the results is provided by Breuer et al. [5].

${ }^{6}$ At the time of writing, data from Denmark and the Netherlands were not available. Furthermore, because of missing values across the covariates, Hungary was omitted from the analysis.
} 
Table 1 Studies on the impact of sport participation on subjective well-being (in chronological order)

\begin{tabular}{|c|c|c|c|c|}
\hline Authors & Country & Data & Estimator & Central findings \\
\hline Becchetti et al. [3] & Germany & $\begin{array}{l}\text { German Social Economic } \\
\text { Panel (GSOEP) }\end{array}$ & $\begin{array}{l}\text { Ordinary least squares (OLS) } \\
\text { and fixed effects (FE) }\end{array}$ & $\begin{array}{l}\text { Relational goods, including sports participation } \\
\text { individually and collectively increases life satisfaction }\end{array}$ \\
\hline Lechner [30] & Germany & $\begin{array}{l}\text { German Social Economic } \\
\text { Panel (GSOEP) }\end{array}$ & Matching estimator & $\begin{array}{l}\text { Significant effects of sport participation upon SWB of } \\
\text { males are identified but positive and insignificant } \\
\text { effects for females }\end{array}$ \\
\hline $\begin{array}{l}\text { Rasciute and } \\
\text { Downward [36] }\end{array}$ & UK & UK Taking Part Survey & $\begin{array}{l}\text { Bivariate and ordered probit, } \\
\text { seemingly unrelated } \\
\text { regression (SUR) }\end{array}$ & $\begin{array}{l}\text { Sports participation and walking have a positive effect } \\
\text { on both the individual's health and happiness. Cycling } \\
\text { also appears to involve some negative impact on } \\
\text { happiness, which could be the disutility associated } \\
\text { with traffic congestion }\end{array}$ \\
\hline $\begin{array}{l}\text { Downward and } \\
\text { Rasciute [13] }\end{array}$ & UK & UK Taking Part Survey & $\begin{array}{l}\text { Heterogeneous threshold } \\
\text { ordered probit estimator }\end{array}$ & $\begin{array}{l}\text { Sports participation increases SWB generally, but more } \\
\text { so in the context of social interactions (team sports } \\
\text { and sports undertaken with a partner) }\end{array}$ \\
\hline Lee and Park [31] & Korea & Primary data & $\begin{array}{l}\text { Ordered probit, ordered } \\
\text { logit and OLS }\end{array}$ & $\begin{array}{l}\text { Controlling for six different types of physical disability } \\
\text { it is shown that sports participation raises the } \\
\text { probability of higher levels of SWB }\end{array}$ \\
\hline
\end{tabular}

years, as well as age-squared to control for a possible quadratic relationship, sex $(\operatorname{men}=1)$, household size, years of education, currently in education, marital status (couple, divorced, separated, widowed, reference category single), employment status (full-time employment, part-time employment, reference category not employed), as well as income.

The treatment of income in the current research required some manipulation. Two strategies were adopted. In one case, all country-specific incomes were transformed into a net annual US dollar purchasing power equivalent income estimate. Therefore, initially all income estimates were divided by the country-specific purchasing power parity exchange rate (PPP). This is given a local currency unit per international dollar and was obtained from the United Nations' webpage. Secondly, in all cases but Great Britain, Ireland, Norway and Slovakia, in which annual income was presented, monthly income was multiplied by 12 to obtain annual income for all countries. Finally, for some countries, the income estimates had to be transformed from gross into net values. This was achieved by calculating a tax rate ' $t$ ' as the ratio of a country's annual income tax revenues to gross domestic product (GDP). Net incomes were generated by multiplying gross incomes from the actual data by a factor calculated as ' 1 ' minus the implied tax rate, ' $t$ '. The second strategy, to check the robustness of this transformation, involved using the standardized measures of each country's income series to remove differences in the levels and variances of the differently recorded incomes. A

\footnotetext{
${ }^{7}$ Note that this approximation might be biased since it does not consider social insurance charges which can be high (for instance in Norway or Sweden). Furthermore, GDP contains factors that do not reflect the household's income, i.e. exports or public expenditures.
}

dummy variable was constructed to be scored ' 1 ' whenever 'negative' income was recorded according to the standardised measure and it was included in the regression analysis with the standardized income measures to check for the sign of effects. Since the analysis of the effect of income on SWB is not of major interest within this study and the standardised measures produced rather similar results, they are omitted for the economy of presentation. ${ }^{8}$

Furthermore and as discussed before, it is assumed that interpersonal differences in happy might be explained due to differences in engagement in physical activity. Consequently, the frequency of engagement in physical activity (physical activity) serves as explanatory variable in our analysis. Like happy, physical activity is treated as continuous with the five categories being never $(=1)$, several times a year or less $(=2)$, several times a month $(=3)$, several times a week $(=4)$ and daily $(=5)$. To detect possible age-specific effects of physical activity on SWB, a complete model with all age groups is estimated as well as separate models for different age groups. All in all, we distinguish between six age groups (25 years and younger, 26-35 years, 36-45 years, 46-60 years, 61-70 years and 71 years and older).

The treatment of happy and sport as continuous variables is an issue that can be debated. Theoretically, one might argue that an ordered measurement of SWB and binary covariates would be most suitable. However, the SWB research has shown that the choice of estimator is not of significance in the findings [17, 36]. There are other advantages too. The interpretation of linear estimators is more straightforward, likely heteroscedasticity from 'lumpy' variation can be controlled for and, more impor-

\footnotetext{
${ }^{8}$ They are available on request
} 
tantly, estimators to control for endogeneity are much more well developed.

The issue of endogeneity is, as rightly noted by Forrest and McHale [18] and Huang and Hunmphreys [25], an important one in sport research. It is intuitively plausible to expect that a feedback between SWB, perhaps mediated by health, and sports participation will exist. Further, this is likely to be associated with age. In the current research, therefore, it is imperative to try to control for this. Whereas these studies used proximity to sports facilities to identify participation in physical activity within a manually implemented two-stage least squares approach, ${ }^{9}$ here, a two-step generalised method of moments estimator (GMM) is employed in which two variables are used, and tested, as instruments. The aim, of course, is to make the use of variables that are at least more closely correlated with sports participation than SWB directly. The first variable measures the frequency of attending sports events (never, several times a year or less, several times a month, several times a week or daily). Alhough, it might be assumed that attending sports events can increase SWB, it is not clear that this automatically raises SWB, as it might depend on the outcome of the event for instance. However, it is more likely that there is interest in sport as a passive viewer and an active participant (e.g. [11]). The second variable employed measures the individuals' participation in a sports association/group in the last 12 months (never, once or twice, several times, at least once a month and at least once a week). The reason for choosing this variable is that the membership of a group can be viewed more as a 'stock' decision in, say, a voluntary sports club system, through which participation can occur than being of an influence on SWB directly [12]. ${ }^{10}$ To control for possible heteroscedasticity caused by the measurement of the variables and other sources and to control for the unobserved heterogeneity between the countries, the GMM estimator is employed with clusters for the 19 European countries.

\section{Results}

As well as providing the names and descriptions of the dependent variable and covariates for the whole sample, Table 2 also presents their unconditional and conditional summary statistics (mean and standard deviation). From an unconditional perspective on average, people are happy

\footnotetext{
${ }^{9}$ In Huang and Humphreys [25], a linear probability model of participation was estimated in which facilities acted as a regressor. The predicted probabilities were then used in a regression modelling SWB.

${ }^{10}$ This is not to say that membership is not connected with the accrual of human or social capital. In a voluntary sports club system, the participant can be seen to be a producer-consumer of sport. The former is facilitated by voluntary activity (see Downward et al. [12]).
}

(mean, 3.039) with their life. Furthermore, on average, people practise sports several times a month (mean, 2.925). The average household's annual net income measures around US \$22,859 PPP. Furthermore, respondents have 12 years of education and live in a household of around three persons. Nearly $60 \%$ of respondents are couples and around $50 \%$ of respondents are employed full-time.

However, as can be seen further, some significant agespecific differences exist: with increasing age, people seem to be (on average) less happy. For instance, while people aged 25 years or younger are on average fairly happy (mean, 3.178), people aged 71 or older are on average not very happy (mean, 1.930). Furthermore, with increasing age, people are (on average) less active. While the mean value of the activity level of people aged 25 years or younger is around 3.178, indicating a level of being physically active between several times a month and several times a week, the mean value of the activity level for people aged 70 years or older measures around 2.580, indicating a level of being physically active between several times a month and several times a year or less. As could be expected, further factors associated with SWB like marital and employment status also show age-specific different mean values and standard deviations.

Furthermore, as expected, some differences exist between the countries, which are suggestive of cultural or national relativities. For the economy of presentation, and since a major focus is put on differences across countries, Table 3 provides an overview of the descriptive statistics (mean, standard deviation) of the variables happy as well as physical activity.

While people living in Ireland (mean, 3.44), Switzerland (3.33), Great Britain (mean, 3.25) or Flanders (mean, 3.22) tend to be fairly happy, people living in Russia (mean, 2.60), Bulgaria (mean, 2.75) or Latvia (mean, 2.79) tend to be less happy. Furthermore, considerable differences concerning the mean values of activity levels between the different countries exist. For instance, people living in Cyprus (mean, 1.76) and Bulgaria (1.87) have a rather low level of physical activity while the activity level is on average highest in Switzerland (3.70) as well as Sweden (3.64) and Norway (3.59). The latter findings are in line with results of the Special Eurobarometer 334 (e.g. [39]), where it was found that "overall, citizens of the Nordic countries take sport most seriously, with Sweden (72\%), Finland (72\%) and Denmark (64\%) all outstripping the EU average of $40 \%$ for people exercising 'regularly' or 'with some regularity' (once a week or more)" (pp. 9-10). Interestingly, all country-specific mean values described above are accompanied by quite large standard deviations. This means that some significant variation in the values is left to be explained by further variables. 


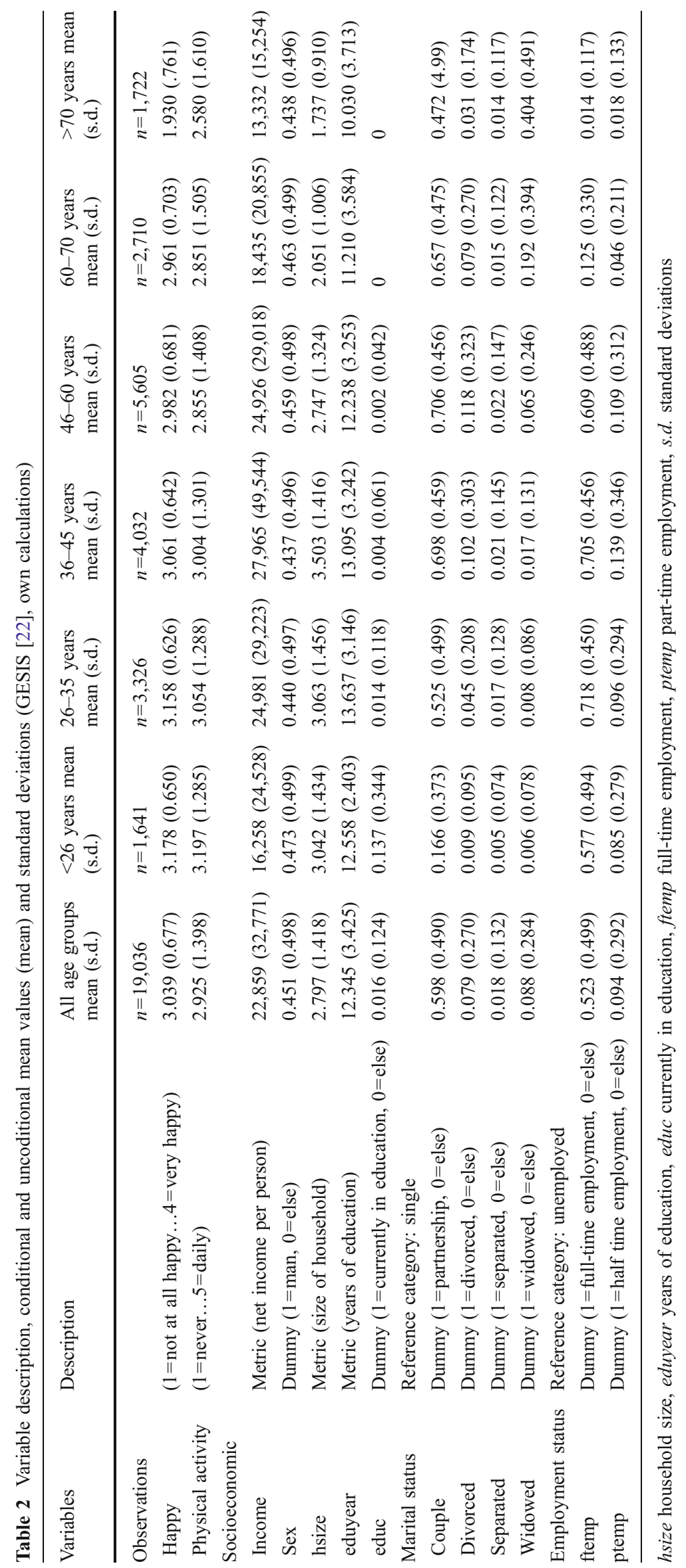


Table 3 Descriptive statistics per country (GESIS [22], own calculations)

s.d. standard deviations

\begin{tabular}{lrcc}
\hline Country & $n$ & Happy mean (s.d.) & Physical activity mean (s.d.) \\
\hline 1. Austria & 886 & $3.14(0.589)$ & $3.19(1.184)$ \\
2. Bulgaria & 693 & $2.75(0.787)$ & $1.87(1.275)$ \\
3. Croatia & 934 & $2.81(0.758)$ & $2.68(1.589)$ \\
4. Cyprus & 884 & $3.07(0.682)$ & $1.76(.978)$ \\
5. Czech Republic & 981 & $3.12(0.566)$ & $2.98(1.300)$ \\
6. Finland & 851 & $2.97(0.631)$ & $3.65(1.017)$ \\
7. Flanders & 973 & $3.22(0.577)$ & $2.75(1.167)$ \\
8. France & 1,359 & $2.85(0.664)$ & $3.28(1.086)$ \\
9. Germany & 1,379 & $3.04(0.612)$ & $3.23(1.318)$ \\
10. Great Britain & 590 & $3.25(0.608)$ & $3.45(1.280)$ \\
11. Ireland & 1,743 & $3.44(0.583)$ & $3.12(1.460)$ \\
12. Latvia & 736 & $2.79(0.641)$ & $2.70(1.519)$ \\
13. Norway & 907 & $3.25(0.593)$ & $3.59(.981)$ \\
14. Poland & 1,000 & $3.08(0.677)$ & $2.11(1.444)$ \\
15. Russia & 1,454 & $2.60(0.707)$ & $2.09(1.346)$ \\
16. Slovakia & 958 & $2.83(0.620)$ & $2.63(1.312)$ \\
17. Slovenia & 781 & $2.95(0.617)$ & $3.13(1.394)$ \\
18. Sweden & 1,005 & $3.17(0.589)$ & $3.64(1.002)$ \\
19. Switzerland & 922 & $3.33(0.575)$ & $3.70(1.166)$ \\
$\sum$ & 19,036 & $3.04(0.677)$ & $2.93(1.398)$ \\
& & &
\end{tabular}

Table 4 presents the results for a total of seven different models based on the two-step efficient GMM estimator clustered for $n=19$ European countries. While the first column presents the results of the model with all age groups together (model 1), the other columns show the results of the age-specific subsamples (models 2-7). Consequently, age and age-squared serve as explanatory variables only in model 1 and are omitted in models 2-7. Furthermore, since no variation could be detected (see Table 2), educ is omitted in models 6 and 7. For each model, the estimated coefficients and $z$ statistics are provided. Coefficients marked with three asterisks, two asterisks or single asterisk are significant at 1\%, 5\%, 10\% levels, respectively. The root mean-squared error, the Kleibergen-Paaprk LM statistics (underidentification test) and the Hansen $\mathrm{J}$ statistics (overidentification test) are displayed for all seven models. ${ }^{11}$

Examining the Kleibergen-Paap rk LM statistics, the null hypotheses which states that the equations are underidentified, can be rejected for all seven models. Therefore, the excluded two instruments (the frequency of attending sports events as well as individuals' participation in a sports association/group) are relevant, meaning these are correlated with physical activity. Furthermore, as indicated by Hansen $\mathrm{J}$ statistics, the joint null hypothesis that the

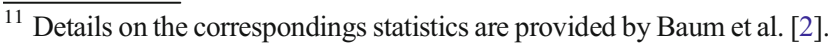

instruments are valid, i.e. uncorrelated with the error term, cannot be rejected. ${ }^{12}$

As noted in the literature, in the overall model with all age groups, a quadratic effect of age on SWB is identified. Furthermore, greater household size and being a couple, rather than being widowed, contributes positively to SWB. In addition, work status other than being not employed contributes to SWB as does income. However, neither the effects of being divorced or separated nor the gender effect are significant (see model 1). As indicated by the results of the subsample estimations, these effects partly vary between different age groups. For instance, income is only significantly positive for those aged 25 years or younger as well as for those aged 46-60 years. ${ }^{13}$ A greater household contributes positively to SWB only for those aged 25 years or younger as well as for those aged 36-45 years while

\footnotetext{
${ }^{12}$ Please note that similarly to Forrest and McHale [18] and Huang and Humphreys [25], we have tested a third variable as a possible instrument, which on a four-point scale (very much, to a large extent, to some extent and not at all), inquiries to what extent the lack of facilities nearby prevents the individuals from doing activities they would like to do on free time. Although not sport specific, this variable has a clear relevance for sport as a non-obligated leisure activity. However, as indicated by Hansen $J$ statistics, the joint null hypothesis that all three instruments are valid, i.e. uncorrelated with the error term, could be rejected for some of the age-specific models. Therefore, this variable was not used as an instrument here.

${ }^{13}$ Please note again that due to the considerable manipulations of the income variable, the estimates have to be interpreted with caution.
} 
Table 4 Results of the two-step efficient generalized method of moments estimator clustered for countries (data source: GESIS [22], own calculations)

\begin{tabular}{|c|c|c|c|c|c|c|c|}
\hline & $\begin{array}{l}\text { Model } 1 \\
\text { All age } \\
\text { groups }\end{array}$ & $\begin{array}{l}\text { Model } 2 \\
<26 \text { years }\end{array}$ & $\begin{array}{l}\text { Model } 3 \\
26-35 \\
\text { years }\end{array}$ & $\begin{array}{l}\text { Model } 4 \\
36-45 \\
\text { years }\end{array}$ & $\begin{array}{l}\text { Model } 5 \\
46-60 \\
\text { years }\end{array}$ & $\begin{array}{l}\text { Model } 6 \\
60-70 \\
\text { years }\end{array}$ & $\begin{array}{l}\text { Model } 7 \\
>70 \text { years }\end{array}$ \\
\hline Constant & $\begin{array}{l}2.8735 \\
(18.07)^{\mathrm{a}}\end{array}$ & $\begin{array}{l}2.4994 \\
(15.74)^{\mathrm{a}}\end{array}$ & $\begin{array}{l}2.3441 \\
(22.15)^{\mathrm{a}}\end{array}$ & $\begin{array}{l}2.1183 \\
(19.28)^{\mathrm{a}}\end{array}$ & $\begin{array}{l}2.1603 \\
(22.58)^{\mathrm{a}}\end{array}$ & $\begin{array}{l}2.1619 \\
(12.90)^{\mathrm{a}}\end{array}$ & $\begin{array}{l}2.4518 \\
(12.16)^{\mathrm{a}}\end{array}$ \\
\hline Physical activity & $\begin{array}{l}0.1787 \\
(7.57)^{\mathrm{a}}\end{array}$ & $\begin{array}{l}0.1283 \\
(4.18)^{\mathrm{a}}\end{array}$ & $\begin{array}{l}0.1379 \\
(5.36)^{\mathrm{a}}\end{array}$ & $\begin{array}{l}0.1741 \\
(5.53)^{\mathrm{a}}\end{array}$ & $\begin{array}{l}0.1820 \\
(8.05)^{\mathrm{a}}\end{array}$ & $\begin{array}{l}0.2612 \\
(8.12)^{\mathrm{a}}\end{array}$ & $\begin{array}{l}0.1879 \\
(3.87)^{\mathrm{a}}\end{array}$ \\
\hline \multicolumn{8}{|l|}{ Socioeconomics } \\
\hline Income & $\begin{array}{l}0.00000102 \\
(2.75)^{\mathrm{a}}\end{array}$ & $\begin{array}{l}0.00000123 \\
(2.23)^{\mathrm{b}}\end{array}$ & $\begin{array}{l}0.00000084 \\
(1.26)\end{array}$ & $\begin{array}{l}0.00000058 \\
(2.18)^{\mathrm{b}}\end{array}$ & $\begin{array}{l}0.00000174 \\
(2.97)^{\mathrm{a}}\end{array}$ & $\begin{array}{l}0.00000050 \\
(0.42)\end{array}$ & $\begin{array}{l}0.00000170 \\
(1.08)\end{array}$ \\
\hline Age & $\begin{array}{l}-0.0294 \\
(-7.65)^{\mathrm{a}}\end{array}$ & & & & & & \\
\hline Age2 & $\begin{array}{l}0.0003 \\
(8.64)^{\mathrm{a}}\end{array}$ & & & & & & \\
\hline Sex & $\begin{array}{l}-0.0020 \\
(-0.12)\end{array}$ & $\begin{array}{l}-0.0351 \\
(-0.93)\end{array}$ & $\begin{array}{l}-0.0098 \\
(-0.42)\end{array}$ & $\begin{array}{l}-0.0043 \\
(-0.18)\end{array}$ & $\begin{array}{l}0.0138 \\
(0.74)\end{array}$ & $\begin{array}{l}0.0258 \\
(0.86)\end{array}$ & $\begin{array}{l}-0.0087 \\
(-0.17)\end{array}$ \\
\hline hsize & $\begin{array}{l}0.0147 \\
(2.30)^{\mathrm{b}}\end{array}$ & $\begin{array}{l}0.0451 \\
(3.00)^{\mathrm{a}}\end{array}$ & $\begin{array}{l}0.0105 \\
(1.13)\end{array}$ & $\begin{array}{l}0.0321 \\
(3.27)^{\mathrm{a}}\end{array}$ & $\begin{array}{l}0.0013 \\
(0.14)\end{array}$ & $\begin{array}{l}0.0046 \\
(0.27)\end{array}$ & $\begin{array}{l}0.0118 \\
(0.48)\end{array}$ \\
\hline eduyears & $\begin{array}{l}0.0050 \\
(1.43)\end{array}$ & $\begin{array}{l}0.0018 \\
(0.15)\end{array}$ & $\begin{array}{l}0.0141 \\
(2.84)^{\mathrm{a}}\end{array}$ & $\begin{array}{l}0.0025 \\
(0.49)\end{array}$ & $\begin{array}{l}-0.0040 \\
(-1.00)\end{array}$ & $\begin{array}{l}0.0036 \\
(0.69)\end{array}$ & $\begin{array}{l}0.0121 \\
(2.01)^{\mathrm{b}}\end{array}$ \\
\hline educ & $\begin{array}{l}0.0618 \\
(0.84)\end{array}$ & $\begin{array}{l}0.0986 \\
(1.06)\end{array}$ & $\begin{array}{l}0.0345 \\
(0.51)\end{array}$ & $\begin{array}{l}0.2433 \\
(1.33)\end{array}$ & $\begin{array}{l}0.0100 \\
(0.07)\end{array}$ & Dropped & Dropped \\
\hline \multicolumn{8}{|l|}{ Marital status } \\
\hline Couple & $\begin{array}{l}0.1996 \\
(5.87)^{\mathrm{a}}\end{array}$ & $\begin{array}{l}0.1573 \\
(3.31)^{\mathrm{a}}\end{array}$ & $\begin{array}{l}0.1896 \\
(5.89)^{\mathrm{a}}\end{array}$ & $\begin{array}{l}0.2272 \\
(8.30)^{\mathrm{a}}\end{array}$ & $\begin{array}{l}0.2727 \\
(5.90)^{\mathrm{a}}\end{array}$ & $\begin{array}{l}0.0317 \\
(0.25)\end{array}$ & $\begin{array}{l}-0.0695 \\
(-0.77)\end{array}$ \\
\hline Widowed & $\begin{array}{l}-0.1523 \\
(-3.18)^{\mathrm{a}}\end{array}$ & $\begin{array}{l}-0.2277 \\
(-1.96)^{b}\end{array}$ & $\begin{array}{l}-0.1225 \\
(-1.00)\end{array}$ & $\begin{array}{l}-0.1874 \\
(-2.14)^{\mathrm{b}}\end{array}$ & $\begin{array}{l}-0.0765 \\
(-1.10)\end{array}$ & $\begin{array}{l}-0.2351 \\
(-1.74)^{\mathrm{c}}\end{array}$ & $\begin{array}{l}-0.3474 \\
(-5.30)^{\mathrm{a}}\end{array}$ \\
\hline Divorced & $\begin{array}{l}-0.0342 \\
(-0.72)\end{array}$ & $\begin{array}{l}-0.3637 \\
(-4.19)^{\mathrm{a}}\end{array}$ & $\begin{array}{l}-0.0883 \\
(-1.28)\end{array}$ & $\begin{array}{l}-0.0316 \\
(-0.99)\end{array}$ & $\begin{array}{l}0.0583 \\
(1.21)\end{array}$ & $\begin{array}{l}-0.1809 \\
(-1.20)\end{array}$ & $\begin{array}{l}-0.3052 \\
(-2.48)^{\mathrm{a}}\end{array}$ \\
\hline Separated & $\begin{array}{l}0.0340 \\
(0.79)\end{array}$ & $\begin{array}{l}0.0469 \\
(0.12)\end{array}$ & $\begin{array}{l}0.0026 \\
(0.02)\end{array}$ & $\begin{array}{l}-0.0310 \\
(-0.67)\end{array}$ & $\begin{array}{l}0.0765 \\
(1.25)\end{array}$ & $\begin{array}{l}0.1534 \\
(1.21)\end{array}$ & $\begin{array}{l}-0.2057 \\
(-2.35)^{\mathrm{b}}\end{array}$ \\
\hline $\begin{array}{l}\text { Employment } \\
\text { status }\end{array}$ & & & & & & & \\
\hline ftemp & $\begin{array}{l}0.1126 \\
(5.22)^{\mathrm{a}}\end{array}$ & $\begin{array}{l}0.1235 \\
(2.40)^{\mathrm{b}}\end{array}$ & $\begin{array}{l}0.0832 \\
(2.46)^{\mathrm{a}}\end{array}$ & $\begin{array}{l}0.1237 \\
(2.46)^{\mathrm{a}}\end{array}$ & $\begin{array}{l}0.1206 \\
(5.01)^{\mathrm{a}}\end{array}$ & $\begin{array}{l}0.1137 \\
(1.70)^{\mathrm{c}}\end{array}$ & $\begin{array}{l}0.2392 \\
(2.53)^{\mathrm{a}}\end{array}$ \\
\hline ptemp & $\begin{array}{l}0.1089 \\
(5.16)^{\mathrm{a}}\end{array}$ & $\begin{array}{l}0.1521 \\
(2.32)^{b}\end{array}$ & $\begin{array}{l}0.0067 \\
(0.15)\end{array}$ & $\begin{array}{l}0.1611 \\
(3.69)^{\mathrm{a}}\end{array}$ & $\begin{array}{l}0.1359 \\
(4.32)^{\mathrm{a}}\end{array}$ & $\begin{array}{l}0.0300 \\
(0.58)\end{array}$ & $\begin{array}{l}0.0254 \\
(0.30)\end{array}$ \\
\hline Observations $(n)$ & 19.036 & 1.641 & 3.326 & 4.032 & 5.605 & 2.710 & 1.722 \\
\hline Root MSE & 0.66 & 0.6483 & 0.6158 & 0.6252 & 0.6656 & 0.7077 & 0.742 \\
\hline $\begin{array}{l}\text { Kleibergen-Paaprk } \\
\text { LM statistics }\end{array}$ & $1,889.098$ & 238.801 & 392.03 & 498.501 & 516.177 & 206.925 & 128.875 \\
\hline Hansen J & 0.418 & 0.431 & 0.033 & 0.503 & 0.755 & 0.705 & 0.145 \\
\hline
\end{tabular}

hsize household size, eduyear years of education, educ currently in education, ftemp full-time employment, ptemp part-time employment, MSE mean-squared error

${ }^{\text {a }}$ Significant at $1 \%$ level

${ }^{\mathrm{b}}$ Significant at $5 \%$ level

${ }^{\mathrm{c}}$ Significant at $10 \%$ level 
education contributes positively to those aged $26-35$ years. Being a couple contributes to SWB for people of all age groups but those aged 60 years or older, no significant effects could be detected. However (and not surprisingly), those aged 60 years or older and having suffered bereavement are less happy compared to singles of the same age.

In general, engagement in physical activity has a significant positive effect on SWB. Interestingly, although for all age groups highly significant and positive, the magnitude of these effects varies across the different age groups. With increasing age, the estimated effect of physical activity on SWB increases (from 0.128 for those aged 25 years or younger to 0.261 for those aged 60 70 years). However, with a value of 0.188 , the estimated effect of physical activity on SWB is rather low for those aged 70 years and older.

\section{Discussion and conclusion}

Although it is well documented that sports participation itself is influenced by age, previous research on factors associated with SWB did not consider a possible interaction effect between age, sports participation or engagement in physical activity and SWB. This article provides a first insight and therefore unique contribution by exploring the age-specific effects of physical activity on SWB.

Overall, the results suggest that sports engagement generally contributes to the SWB of individuals on a European level. The results thus give impetus to the growing public policy that seeks to promote sport to raise the SWB of citizens. However, age-specific differences concerning the (marginal) impact of physical activity on SWB exist. It appears that being generally physically active contributes the more to SWB the older the individuals are. Considering the fact that the number of older people will rise dramatically within the next decades [24], these results suggest that policy measures that seek to increase engagement in physical activity amongst older people are of significance since the net effect on SWB is the highest.

Further estimations suggest that these findings are robust to the specification of physical activity. Treating physical activity as being cardinal (with never $=0$, several times a year or less $=1$, several times a month $=12$, several times a week $=52$ and daily $=365$ ) reveals a very similar pattern. Nevertheless, our paper suffers from two general limitations: First, the employed overidentification test can only indicate whether the instruments are jointly wrong or not. However, the identification of perfect instruments is not possible based on the available data and the applied statistics in general support of our choice of instrumental variables. Therefore, the chosen estimation strategy appears to be the only one to tackle the problem of reverse causality with the data available here. Second, as discussed in detail by Breuer et al. [5], the basic so-called age effect on physical activity, which can be seen as a proxy for the physical, mental, social and economic characteristics of a certain age group, cannot be obtained by cross-sectional analysis. Moreover, as argued by Breuer and Wicker [6], only period effects can be controlled in this kind of analysis while age and cohort effects are mixed up. To control period as well as age and cohort effects, panel data would be necessary, which are not available for a sample of different European countries at this moment.

Acknowledgements The authors would like to thank two anonymous referees who significantly helped to improve the previous version of the paper.

\section{References}

1. Andersson P (2008) Happiness and health: well-being among the self-employed. J Socio-Econ 37:213-236

2. Baum CF, Schaffer ME, Stillman S (2007) IVREG2: Stata module for extended instrumental variables/2SLS and GMM estimation. Boston Coll Dep Econ, Stat Softw Compon S425401. http://ideas. repec.org/c/boc/bocode/s425401.html. Accessed 20 June 2011

3. Becchetti A, Pelloni A, Rossetti F (2008) Relational goods, sociability, and happiness. Kyklos 61(3):343-363

4. Blanchflower DG, Oswald AJ (2004) Money, sex and happiness: an empirical study. Scand J Econ 106(3):315-415

5. Breuer C, Hallmann K, Wicker P, Feiler S (2010) Socio-economic patterns of sport demand and ageing. Eur Rev Aging Phys Act 7:61-70

6. Breuer C, Wicker P (2009) Decreasing sports activity with increasing age? Findings from a 20-year longitudinal and cohort sequence analysis. Res Q Exerc Sport 80(1):22-31

7. Clark AE, Diener E, Georgellis Y, Lucas RE (2008) Lags and leads in life satisfaction: a test of the baseline hypothesis. Econ $\mathrm{J}$ 118:222-243

8. Clark AE, Etile F, Postel-Vinnay F, Senik C, Van der Straeten K (2005) Heterogeneity in reported well-being: evidence from twelve European countries. Econ J 115(502):118-132

9. Colditz GA (1999) Economic costs of obesity and inactivity. Med Sci Sports Exerc 31(11):663-667

10. DCMS/Strategy Unit (2002) Game plan: a strategy for delivering government's sport and physical activity objectives. London

11. Downward PM, Dawson P (2011) Participation, spectatorship and media coverage in sport: some initial insights. In: Andreff W (ed) Contemporary issues in sports economics. Edward Elgar, London

12. Downward PM, Dawson A, Dejonghe T (2009) Sports economics: theory, evidence and policy. Butterworth, London

13. Downward PM, Rasciute S (2011) Does sport make you happy? An analysis of the well-being derived from sports participation. Int Rev Appl Econ 25(3):331-348

14. Easterlin R (1974) Does economic growth improve the human lot? In: David PA, Reder MW (eds) Nations and households in economic growth essays in honor of Moses Abramovitz. Academic Press, New York, pp 89-125

15. European Commission (2011) Sport satellite accounts. A European project: first results. http://ec.europa.eu/sport/library/doc/b1/ madrid forum sport satellite account leaflet.pdf. Accessed 14 June 2011 
16. Ferrer-i-Carbonell A (2005) Income and well-being: an empirical analysis of the comparison income effect. J Public Econ 89(56):997-1019

17. Ferrer-i-Carbonell A, Frijters P (2004) How important is methodology for the estimates of the determinants of happiness. Econ J 114:641-659

18. Forrest D, McHale I (2009) Public policy, sport and happiness: an empirical study. Salford University, Manchester. Working paper

19. Frey BS, Stutzer A (2002) Happiness and economics: how the economy and institutions affect well-being. Princeton University Press, Princeton

20. Frey BS, Stutzer A (2005) Testing theories of happiness. In: Bruni L, Porta PL (eds) Economics and happiness: framing the analysis. Oxford University Press, Oxford, pp 116-146

21. Frijters P, Geishecker I, Haisken-DeNew JP, Shields MA (2006) Can the large swings in Russian life satisfaction be explained by ups and downs in real incomes? Scand J Econ 108(3):433458

22. GESIS (2009) ISSP 2007 Leisure time and sports survey. LeibnizInstitut für Sozialwissenschaften, Mannheim

23. Gui B (2000) Beyond transactions: on the interpersonal dimension of economic reality. Ann Public Coop Econ 71(2):139-169

24. Hinrichs T, Trampisch U, Burghaus I, Endres H, Klaaßen-Mielke R, Moschny A, Platen P (2010) Correlates of sport participation among community-dwelling elderly people in Germany: a crosssectional study. Eur J Sport Soc 6(1):49-57

25. Huang H, Humphreys BR (2010) Sports participation and happiness: evidence from U.S. micro data. University of Alberta, Edmonton. Working paper no. 2010-09

26. Johnson DR, Wu J (2002) An empirical test of crisis, social selection, and role explanations of the relationship between marital disruption and psychological distress: a pooled timeseries analysis of four-wave panel data. J Marriage Fam 64:211224

27. Kahneman D, Diener E, Schwarz N (1999) Well-being: the foundations of hedonic psychology. Russell, New York

28. Katzmarzyk PT, Gledhill N, Shephard RJ (2000) The economic burden of physical inactivity in Canada. Can Med Assoc J 163 (11): $1435-1440$
29. Kavetsos G, Szymanski S (2010) National well-being and international sports events. J Econ Psychol 31:158-171

30. Lechner M (2009) Long-run labour market and health effects of individual sports activities. J Health Econ 28(4):839-854

31. Lee YH, Park I (2010) Happiness and physical activity in special populations: evidence from Korean survey data. J Sports Econ 11:136-156

32. Maennig W, Porsche M (2008) The feel-good factor at mega sports events. Recommendations for public and private administration informed by the experience of the FIFA World Cup 2006. Hamburg contemporary economic discussions no. 18. Fac Econ SocSci, Univ Hamburg. http://www.uni-hamburg.de/onTEAM/ grafik/1098966615/HCED-18.pdf. Accessed 15 August 2010

33. Mechling H, Netz Y (2009) Aging and inactivity - capitalizing on the protective effect of planned physical activity in old age. Eur Rev Aging Phys Activity 6(2):89-97

34. Oswald AJ, Powdthavee N (2008) Death, happiness, and the calculation of compensatory damages. J Leg Stud 37(S2):217-252

35. Powdthavee N (2010) How much does money really matter? Estimating the causal effects of income on happiness. Empir Econ 39:77-92

36. Rasciute S, Downward PM (2010) Health or happiness? What is the impact of physical activity on the individual. Kyklos 63(2):256-270

37. Shields MA, Wheatley Price S (2005) Exploring the economic and social determinants of psychological well-being and perceived social support in England. J R Stat Soc (A) 168(3):513-537

38. Smala A, Beeler I, Szucs TD (2001) Die Kosten der körperlichenInaktivität in der Schweiz. Zürich

39. TNS Opinion \& Social (2010) Special eurobarometer 334/wave 72.3: sport and physical activity. TNS Opinion \& Social, Brussels

40. Van Praag BMS, Frijters P (1999) The measurement of welfare and well-being: the Leyden approach. In: Kahneman D, Diener E, Schwarz N (eds) Well-being: the foundations of hedonic psychology. Russel Sage Found, New York, pp 413-432

41. Winkelmann L, Winkelmann R (1998) Why are the unemployed so unhappy? Evidence from panel data. Econ 65(257):1-15

42. Winkelmann R (2005) Subjective well-being and the family: results from an ordered probit model with multiple random effects. Empir Econ 30:749-761 